\title{
Anthropophytes in the flora of different spatial units within old rural settlements of the Lubuskie Lakeland, western Poland
}

\author{
Katarzyna Jasińska*, Andrzej Brzeg \& Maria Wojterska
}

Department of Plant Ecology and Environmental Protection, Faculty of Biology, Adam Mickiewicz University, Umultowska 89, 61-614 Poznan.

*corresponding author (e-mail: kszrama@amu.edu.pl)

\begin{abstract}
Studies of the flora of villages in a connection with the surrounding landscape are rare and mostly limited to the built-up area and its general location in a geographical region. Thus, the aim of this study was to examine the diversity patterns of flora against the background of local landscape units in the rural areas and to analyse them in the context of village transformation. The study comprised 30 villages of medieval origin representing the oval-shape type, with differently preserved structure of built-up area and cultivated fields, located in the Lubuskie Lakeland. The terrain within a buffer zone of $200 \mathrm{~m}$ in width, located outside of the built-up area, was divided into spatial complexes. In each of these complexes, floristic lists were compiled. The structure of surrounding landscape within the buffer zone of $1 \mathrm{~km}$ in width, measuring from the village centroid, was analysed using ArcGIS.

The recorded flora comprised 767 taxa of spontaneously occurring vascular plants. Extremely rare and common species were the most numerous. Native species distinctly prevailed over alien in all types of spatial complexes and the majority of them occurred in the habitats transformed by man. There were noted altogether 244 species of anthropophytes.

The index of anthropophytization of flora ( $\left.\mathrm{WAn}_{\mathrm{t}}\right)$ showed that both types of built-up areas (transformed and non-transformed) reached the highest values, slightly higher than fields and central green. Index of flora modernization (WM) showed the same pattern. Only water bodies were strikingly different from other complexes in respect to both indices (WAn - significantly $_{t}$ lower values, while WM - much higher). Differences in the floristic composition of transformed and non-transformed villages were not significant at the level of whole village. The villages were still harbouring rare species from the group of relics of former cultivation and archaeophytes, but observations conducted since 2007 confirmed that they have been decreasing in number. The percentage of groups of species with different affinity toward urban areas have shown that in the studied rural areas, the share of urbanophilic species is still very low as compared to the dominant group of urbanoneutral and moderately urbanophobic species.
\end{abstract}

Key words: vascular flora, anthropophytes, villages, indices of anthropogenic changes, Lubuskie Lakeland, Poland

\section{Introduction}

Human settlements were investigated in numerous geobotanical studies. Research, however, mostly focused on large cities or towns (e.g. Jackowiak 1990; Sukopp 1990; Sudnik-Wójcikowska 1998; Borysiak et al. 2000; Kühn et al. 2004a). The villages harbouring specific flora and vegetation are becoming threatened nowadays by increasing urbanization and homogenization (Huwer \& Wittig 2013), what makes the studies on their flora so important. The diversity of vascular flora of villages was analysed in several papers, e.g.: Hanski (1982), Wittig (1984, 2008), Raabe \& Brandes
(1988), Brandes \& Brandes (1996), Wołkowycki (1997, 2000a, 2000b), Pyšek (1998a), Kim et al. (2002), Kalwasińska-Brojek \& Markowski (2005), Ahrns (2009), Kirpluk (2011, 2012), Knapp \&Wittig (2012), Pal et al. (2013). Some papers concerned only the synanthropic flora, which made the assessment of the role of rural landscape in maintaining the biodiversity difficult. In the case of this landscape type more attention was paid to the arable fields, especially on large scale, e.g.: Weibull \& Östman (2003), Lososová et al. (2004), Pyšek et al. (2005a, 2005b), Lososová \& Cimalová (2009), Balcerkiewicz \& Pawlak (2010), Gunton et al. (2011). 
The small-scale habitat mosaic prevails in urban over rural areas. These habitats differ in the share of nonnative species and forms of human influence (Faliński 1971; Jackowiak 1990; Pyšek 1998a, 1998b). Comparisons between the selected European settlements have shown a positive correlation between the size of settlement and the presence of alien species (Faliński 1971), explained by the fact that cities are the centres of alien species migration (Kowarik 1990; Jackowiak 1998). Alien species were also investigated in various aspects and still are a widely studied topic of contemporary ecological research, which is nowadays particularly focused on invasive plants (Drake et al. 1989; Pyšek et al. 1995, 2003; Tokarska-Guzik 2005; Tokarska-Guzik et al. 2012).

Lack of information on the differentiation of flora within rural areas have drawn our attention to the problem of the diversity patterns of flora in the local spatial units of villages and their surroundings, resulting from the main forms of land use. The oval shaped villages established in the period from the $13^{\text {th }}$ to the $15^{\text {th }}$ century were generally characterized by a very uniform plan, which involved regular arrangement of land strips and planned location of homesteads (Burszta 1958). The homesteads and farmsteads extended around a clearly marked central green assigned to common usage. The fields associated with those villages were regularly divided into long strips (Nitz 1998). This shape gave the convenient basis for studies on spatial differentiation of floras. The historical events contributed to the fact that in the Lubuskie region there were still well preserved rural settlements of medieval origin, and among them the oval shaped villages were the most common (Wojterska et al. 2007a, 2007b). Over the subsequent next centuries, the structural changes occurred in medieval villages, first, as a result of the continuous growth of farms and their number, then, the formation of manor farms, and, later, the consolidation of arable fields during the land reform in the $20^{\text {th }}$ century (Burszta 1958). These changes did not affect all villages, leaving some of them with the well preserved original structure and creating the possibility to estimate the role of landscape structure in their floristic composition.

The aim of this paper was to assess the share of anthropophytes in the flora of different elements of rural landscape as the measure of their anthropogenic changes. Studies concerned the total flora of villages and their vicinity, focusing on the role of alien as compared to that of native species. The alien species were divided into geographic-historical groups and their share was shown against the background of landscape patterns. The obtained results were compared to those from other regions or landscape types.

\section{Material and methods}

\subsection{Study site}

30 villages with the best preserved structure were chosen for floristic studies, out of 68 representing an oval-shaped type and occurring in the region (Fig. 1).

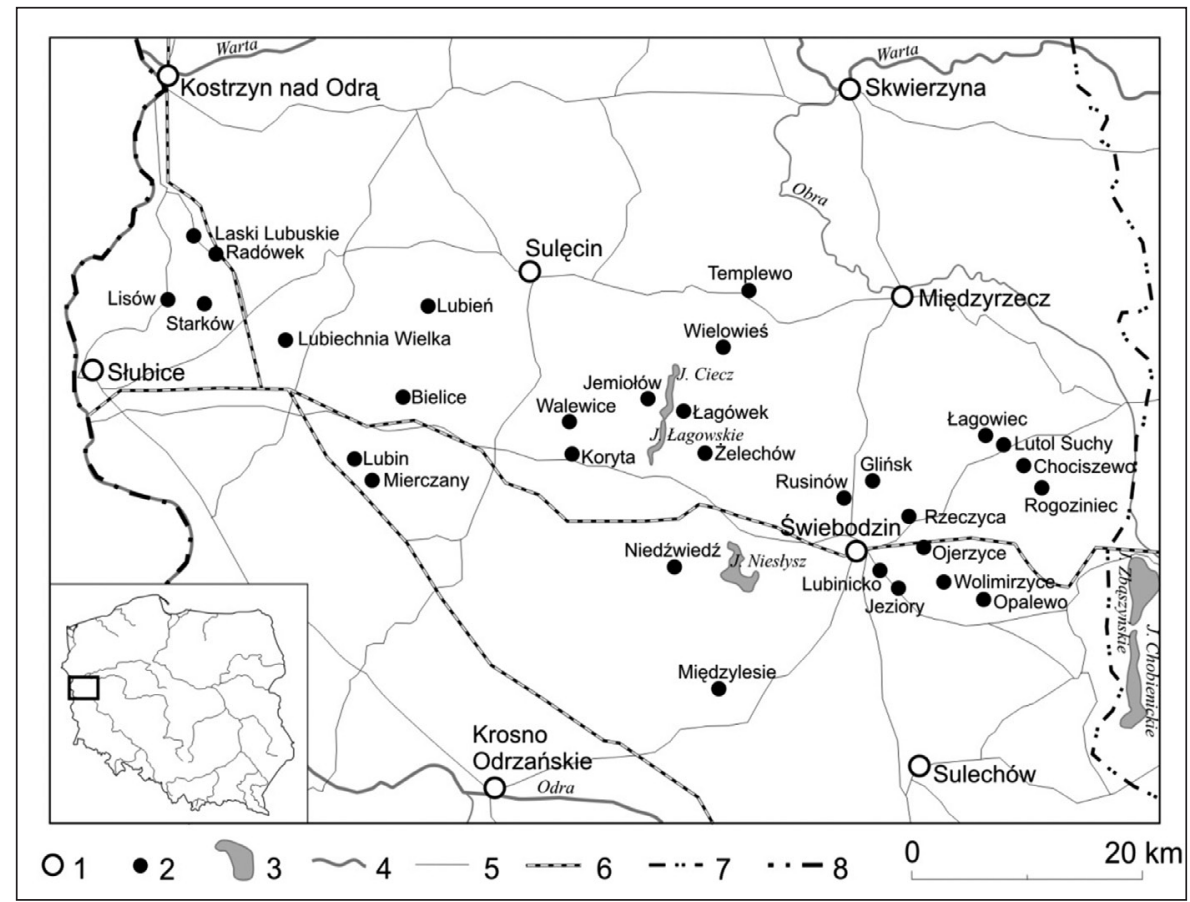

Fig.1. Distribution of studied villages

Explanations: 1 - towns, 2 - villages, 3 - lakes, 4 -rivers, 5 - roads, 6 - railways, 7 - boundary of the voivodship, 8 - state boundary 
Table 1. Set of distinguished types of spatial complexes

\begin{tabular}{lr}
\hline Name & \multicolumn{1}{c}{ Characteristics and abbreviations used in this paper } \\
\hline Built-up area & B1 - traditional built up-area in all villages \\
B1 $\mathrm{t}$ - traditional built-up area in transformed villages \\
B1 nt - traditional built-up area in non-transformed villages \\
B2 - manor house, big grange, block of flats \\
Cent - central area characteristic for villages with oval shape, mostly covered \\
by lawns, buildings and roads
\end{tabular}

The vascular flora of the rural landscape of these villages and their vicinity was studied in the years 2010-2014. All villages were located in the same geographic macroregion, named the Lubuskie Lakeland (Kondracki 1998), mainly in the potential landscape of oak-hornbeam forest Galio sylvatici-Carpinetum with some share of acidophilous oak forest Calamagrostio arundinaceae-Quercetum petraeae, and, occasionally, also xerothermophilous oak forest Potentillo albaeQuercetum, or in the landscape of lowland beech forests Deschampsio flexuosae-Fagetum and acidophilous oak forests (Wojterski et al. 1973; Matuszkiewicz 1993). The study area covered 4 districts and 13 communes regarding the administrative division.

The lists of together 182 most interesting vascular plant species noted in the studied villages were published recently (Brzeg et al. 2013, 2014).

\subsection{Spatial complexes and landscape types}

Albeit the general structure of studied villages was uniform, since they were located according to the same scheme, they differed in the size and spatial structure of landscape in the surroundings. Therefore, the analysed villages were divided in two groups - these with the preserved traditional structure (only 11) and those with changed structure (19 villages). The group of untransformed villages had well preserved built-up area and the surrounding fields were divided into long narrow strips. Contrary to that group, villages with transformed structure had, within their area, a later built manor or large farmstead and were surrounded by blocks of consolidated arable fields.

In each village, a $200 \mathrm{~m}$ wide buffer zone was delineated around the built-up area in the ArcGis 10.0 software. They (i.e., the built-up area and adjacent buffer zone) constituted the study area and were divided into spatial complexes. The complexes were differentiated into built-up areas, central green, arable fields, meadows, forests and water bodies according to the dominant land use type and reflecting the varying human impact. The characteristics of the above mentioned complexes (excluding not analysed meadows and forests) are shown in Table 1. In all villages, the arable fields were divided in two separate groups: a) small fields adjacent to the village and $b$ ) fields of different size situated beyond the road surrounding village. In the villages with changed structure, area was divided in two complexes: a) traditional built-up area, b) manor house, big grange and/or block of flats. In each village, 6-10 spatial complexes were delimited. The traditional built-up area, central green and arable fields were stated in all 30 villages, while water bodies in almost all villages (29).

To assess the surrounding landscape, another, broader buffer zone of $1 \mathrm{~km}$ in width, was drawn from the centroid of each village. Within this zone the percentages of built-up area, arable fields, forests, water bodies and meadows/pastures were calculated. On the basis of these results the surrounding landscape was classified into 3 groups after the index showing the ratio of fields area to that of natural and seminatural elements: a) "arable" (A) -10 villages with value 10-129, b) "mixed" (M) - 9 villages with value 4-9, c) "forest" (F) - 11 villages with value $0.1-3$.

Spatial database was built of data from orthophotomaps and aerial photos digitalized in GIS. The percentages of different types of land use were calculated using Fragstats 4.1 (McGarigal et al. 2012) software.

\subsection{Data collection and analysis}

Floristic lists in all spatially delimited complexes were compiled. Only spontaneously occurring plant species were taken into account. The percentages of anthropophytes and native species were calculated from complete species lists concerning given category in all villages. Names of species were given after Mirek et al. (2002). 
Table 2. Percentage of geographic-historical groups of species in two types of settlements

\begin{tabular}{lccc}
\hline & Untransformed villages & Transformed villages & Difference \\
\hline Sn & 04.8 & 03.4 & -1.4 \\
$\mathrm{Ap}$ & 64.0 & 64.2 & -0.2 \\
$\mathrm{Ar}$ & 13.6 & 13.5 & -0.2 \\
$\mathrm{Erg}$ & 10.4 & 11.0 & -0.6 \\
$\mathrm{Agr}$ & 02.2 & 02.2 & -0.0 \\
Eph & 00.9 & 00.9 & -0.1 \\
Epeko & 04.2 & 05.0 & -0.8 \\
\hline
\end{tabular}

Explanations: Sn - non-synanthropic spontaneophytes, Ap - apophytes, Ar - archaeophytes, Erg - ergasiophytes, Agr - agriophytes, Eph - ephemerophytes, Epeko - epekophytes

The species immigration status was determined using the database of Ratyńska et al. (2010), which was based on the Central-European concepts of geographichistorical groups, well established in the literature (Thellung 1915; Kornaś 1968, 1977; Mirek 1981; Kornaś \& Medwecka-Kornaś 2002) and revised with respect to the local territory. Anthropophytes were divided into metaphytes $(\mathrm{M})$ - permanently established species, and diaphytes (D) - not permanent species. Permanent species were further subdivided into archaeophytes (Ar) and kenophytes (Kn), whereas diaphytes - into ergasiophytes (Erg) - garden escapes, and ephemerophytes (Eph) - transient aliens. Additionally, kenophytes were divided into epekophytes (Epeko) found in anthropogenic vegetation, and agriophytes (Agr) found mainly in natural vegetation. Geographical origin of archaeophytes (Ar) was based on Zając (1979) and Zając et al. (2011), their category of threat on Zając et al. (2009). In case of recently established alien species of vascular plants (kenophytes $-\mathrm{Kn}$ ) classification was based on Zając et al. (1998), Tokarska-Guzik (2005) and Tokarska-Guzik et al. (2012).

Native species were divided in two groups according to the authors' estimation of their status in the studied area (compare Żukowski et al. 1995, p. 24): a) non-synanthropic sponthaneophytes $(\mathrm{Sn})$ - found only in the fragments of natural forests, swamps and water bodies, and b) apophytes (Ap) - found mainly in habitats of anthropogenic origin, such as: built-up areas, arable and abandoned fields, parks, ponds, roads, gravel pits, meadows and pastures. The last two habitats were assessed as anthropogenic acc. to the classification of Faliński (1969).

The anthropogenic transformation of the vascular flora of analysed villages was assessed with the use of following indices defined by Jackowiak (1990): total synanthropization index (WS ) - percentage contribution of apophytes and anthropohytes to the total number of species, total apophytization index $\left(\mathrm{WAp}_{\mathrm{f}}\right)$ - percentage contribution of apophytes to the total number of species, spontaneophyte apophytization (WAp) percentage contribution of apophytes to the number of all spontaneophytes, total anthropophytization index $\left(W_{t}\right)$ - percentage contribution of anthropophytes to the total number of species, total archaeophytization $($ WAr $)$ - percentage contribution of archaeophytes to the total number of species, total kenophytization $\left(\mathrm{WKn}_{t}\right)$ - percentage contribution of kenophytes to the total number of species, flora modernization index (WM) percentage contribution of kenophytes to metaphytes (for formulas see Table 3 ).

The categories of urbanity (Wittig et al. 1985) were used to evaluate contribution of particular groups of urbanophilic, moderately urbanophilic, urbanoneutral, moderately urbanophobic and urbanophobic species in spatial complexes. The information on affiliation of species to the above mentioned categories was taken from BiolFlor Database (Kühn et al. 2004b).

Five classes of species frequencies were established on the basis of the number of villages, in which given species were stated: common (15-30 villages), frequent (10-14), rare (5-9), very rare (3-4), extremely rare (1-2).

\section{Results}

\subsection{Frequency of alien versus native species in the} studied villages

The recorded flora of all investigated villages comprised 767 taxa of spontaneously occurring vascular plants. The number of species varied in particular villages from 179 to 435 (mean 299). About 27\% of species were extremely rare (Fig. 2). Very rare and rare species amounted jointly to $29 \%$, frequent accounted for $12 \%$. Common species were the most numerous - more than $32 \%$. There were noted altogether 244 species of anthropophytes, which constitutes $31.8 \%$ of the total flora. The pattern of contribution of frequency classes of both groups is very similar - the most numerous are extremely rare and common species. To the most infrequent alien species belong e.g.: Anthriscus cerefolium, Bunias orientalis, Camelina sativa, Coronopus squamatus, Corispermum leptopterum, Hyoscyamus niger, Isatis tinctoria, Lepidium campestre (extremely rare), and Anthemis cotula, Carduus nutans, Digitalis 


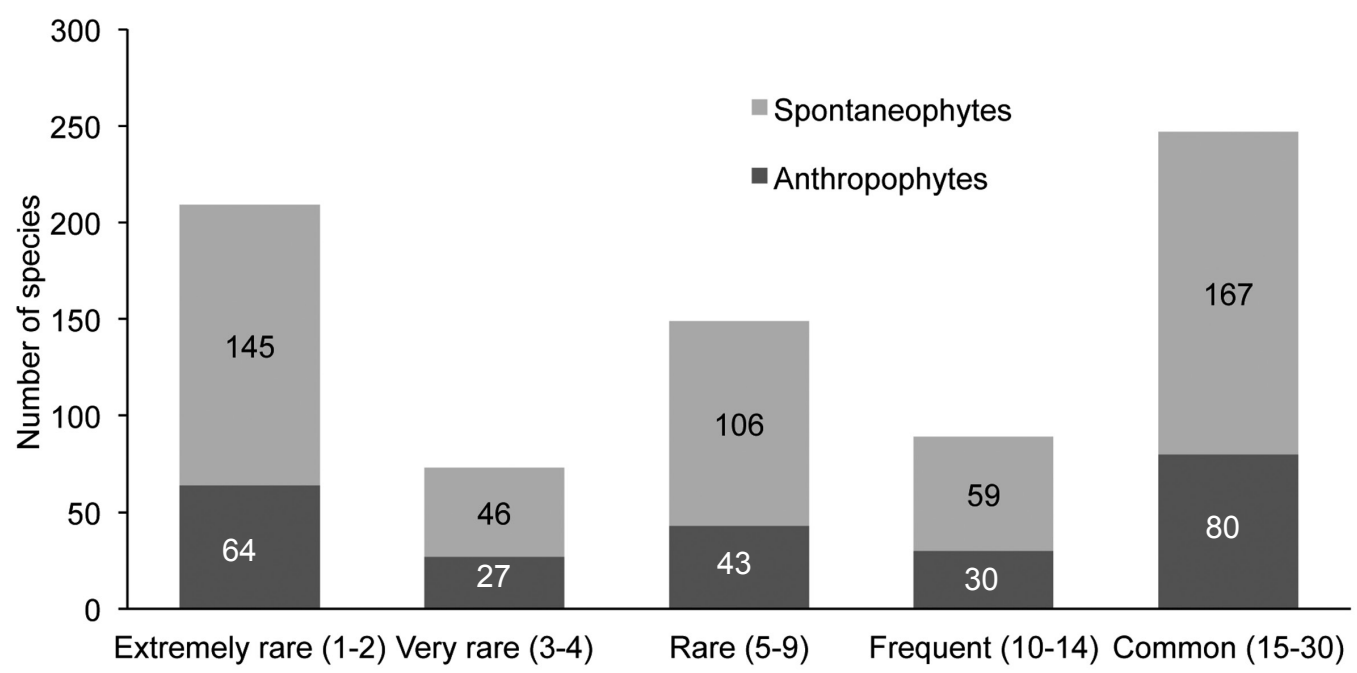

Fig. 2. Number of native (spontaneophytes) and alien species (anthropophytes) in the distinguished frequency classes (in brackets numbers of villages)

purpurea, Echinops sphaerocephalus, Galium spurium and Reseda lutea (very rare). Especially common species found in all 30 villages included, e.g.: Apera spica-venti, Bromus carinatus, Centaurea cyanus, Conyza canadensis, Echinochloa crus-galli, Galinsoga ciliata, G. parviflora, Lactuca serriola, Malva neglecta, Sisymbrium officinale and Viola odorata.

\subsection{Frequency of species in the studied spatial complexes}

The number of species in all types of complexes (except for WB - water bodies) was comparable (Fig. 3) and varied from 387 in manor house and blocks of flats complexes (B2) to 507 in fields directly adjoining built-up area (F1). The WB complex was floristically poorest (134 taxa). The floristic richness seemed not to be related to the area (Fig. 4) of complexes.
The high number of species found in central green, as compared to its area, was striking, whereas larger, farther situated fields were less rich than those in the vicinity of built-up area.

\subsection{Comparison of the share of geographic-historical groups of species}

Analysis of the share of geographic-historical groups indicated that in the flora of all studied villages, the native species (523 taxa) prevailed over anthropophytes (244 taxa) and the most important group constituted apophytes (Fig. 5). In the group of permanently established anthropophytes, the percentage of archaeophytes was higher than of kenophytes. Ephemeral elements - diaphytes, constituted also an important group of species in the studied villages.

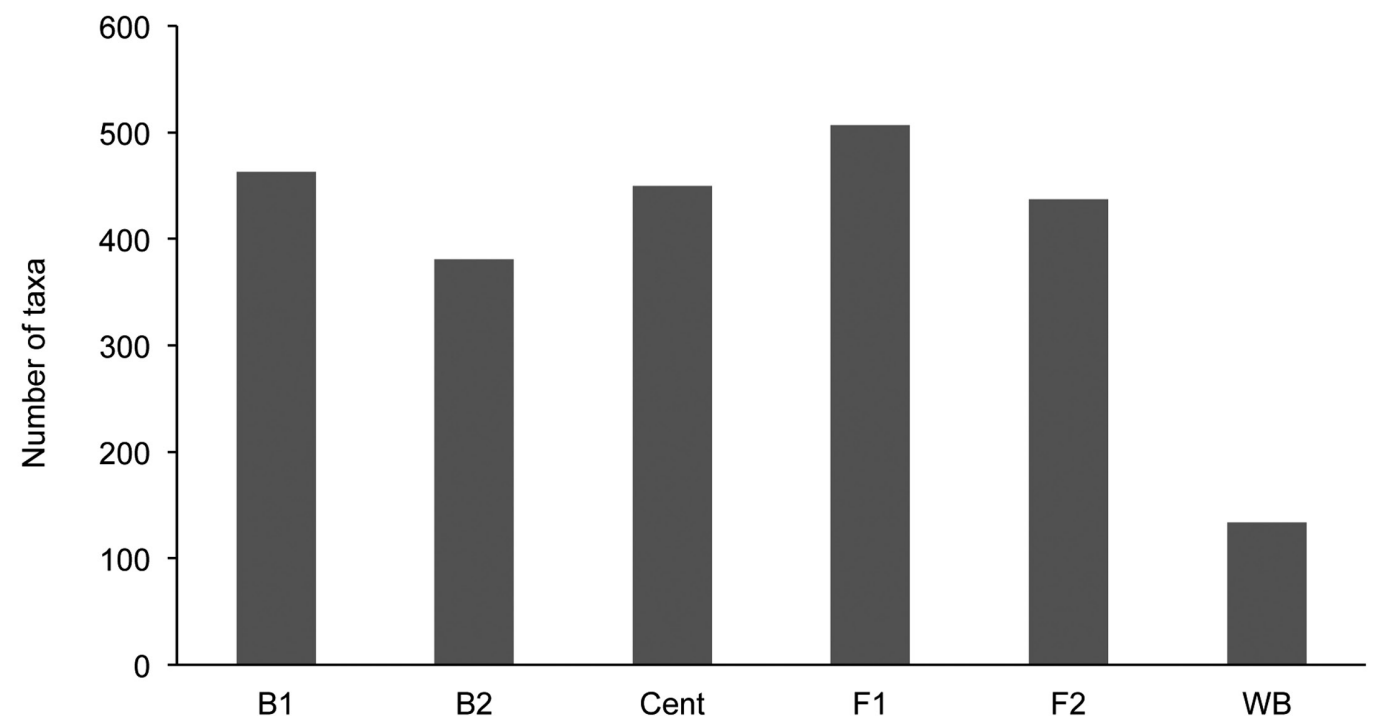

Fig. 3. Total number of species in the differentiated types of spatial complexes 


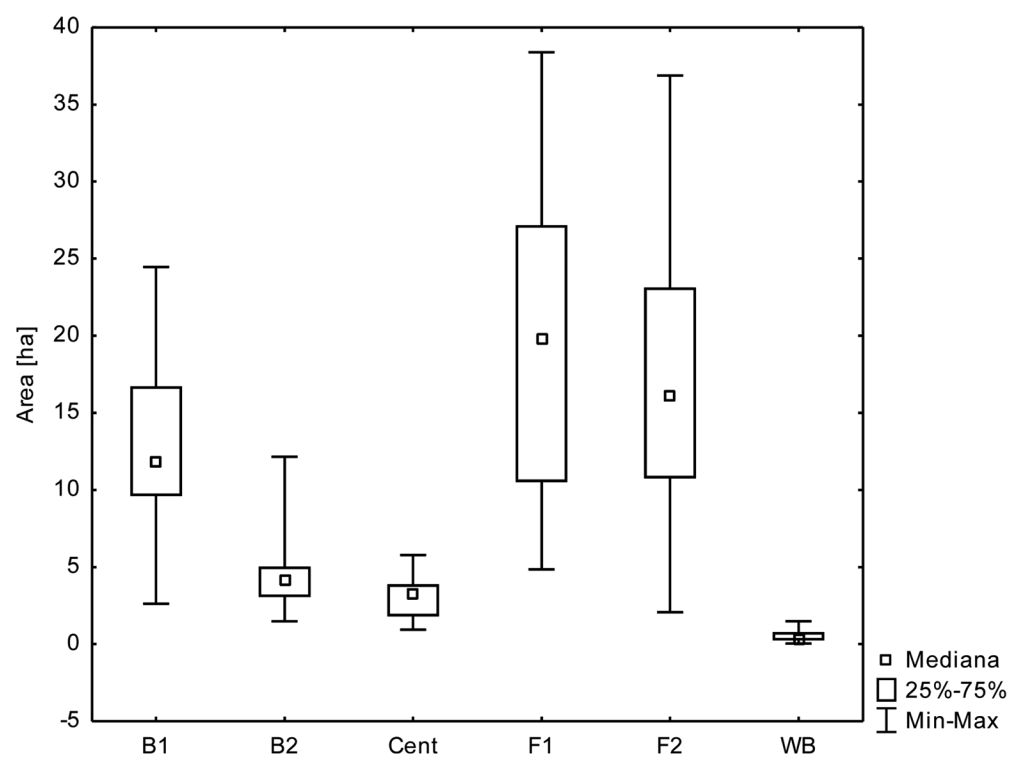

Fig. 4. Differentiation of the area of spatial complexes

The analysis of the contribution of geographic-historical groups to the flora of spatial complexes (Fig. 6) showed that non-synanthropic spontaneophytes were extremely rare or absent in all of them; the relatively highest share of this group was noted in the water bodies complexes $(3 \%)$ and in central green $(2 \%)$. Apophytes prevailed in all complexes with maximum in water bodies complexes $(91 \%)$, and the lowest percentage in the traditional built-up area of transformed villages $(60 \%)$. The shares of archaeophytes were similar in all complexes excluding water bodies, where archaeophytes were noted only occasionally $(2 \%)$. The pattern of share of kenophytes was analogous to that of archaeophytes. The lowest percentage was found in the water bodies complexes (4\%) and the highest in the traditional built-up area in transformed villages (9\%). Ephemeral elements were noted in all complexes excluding water bodies. The highest percentages of diaphytes were found in built-up areas.

Detailed information about the contribution of different groups of kenophytes and diaphytes to the flora of studied spatial complexes is shown in Figure 7. Among the permanent alien species, epekophytes prevailed over agriophytes. In all complexes the

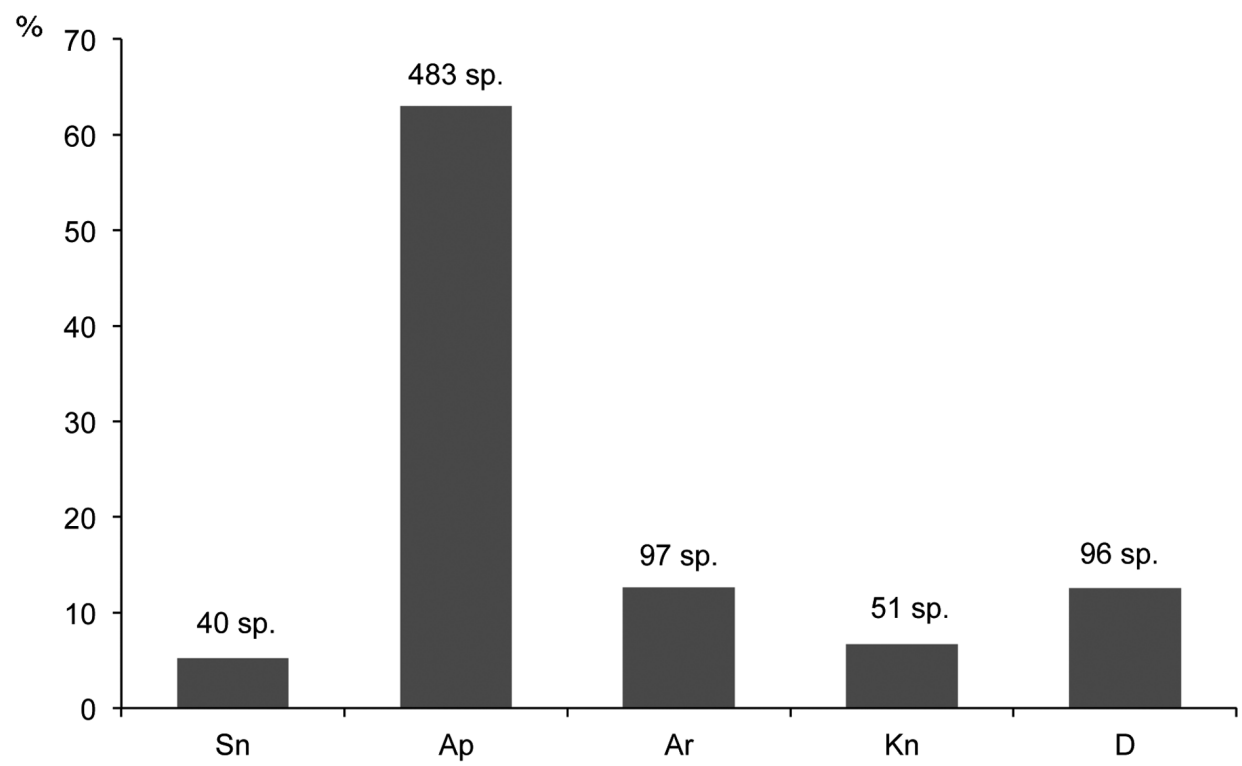

Fig. 5. Contribution of geographic-historical groups of the flora of analysed villages

Explanations: $\mathrm{Sn}$ - non-synanthropic spontaneophytes, $\mathrm{Ap}$ - apophytes, $\mathrm{Ar}$ - archaeophytes, $\mathrm{Kn}$ - kenophytes, D - diaphytes 


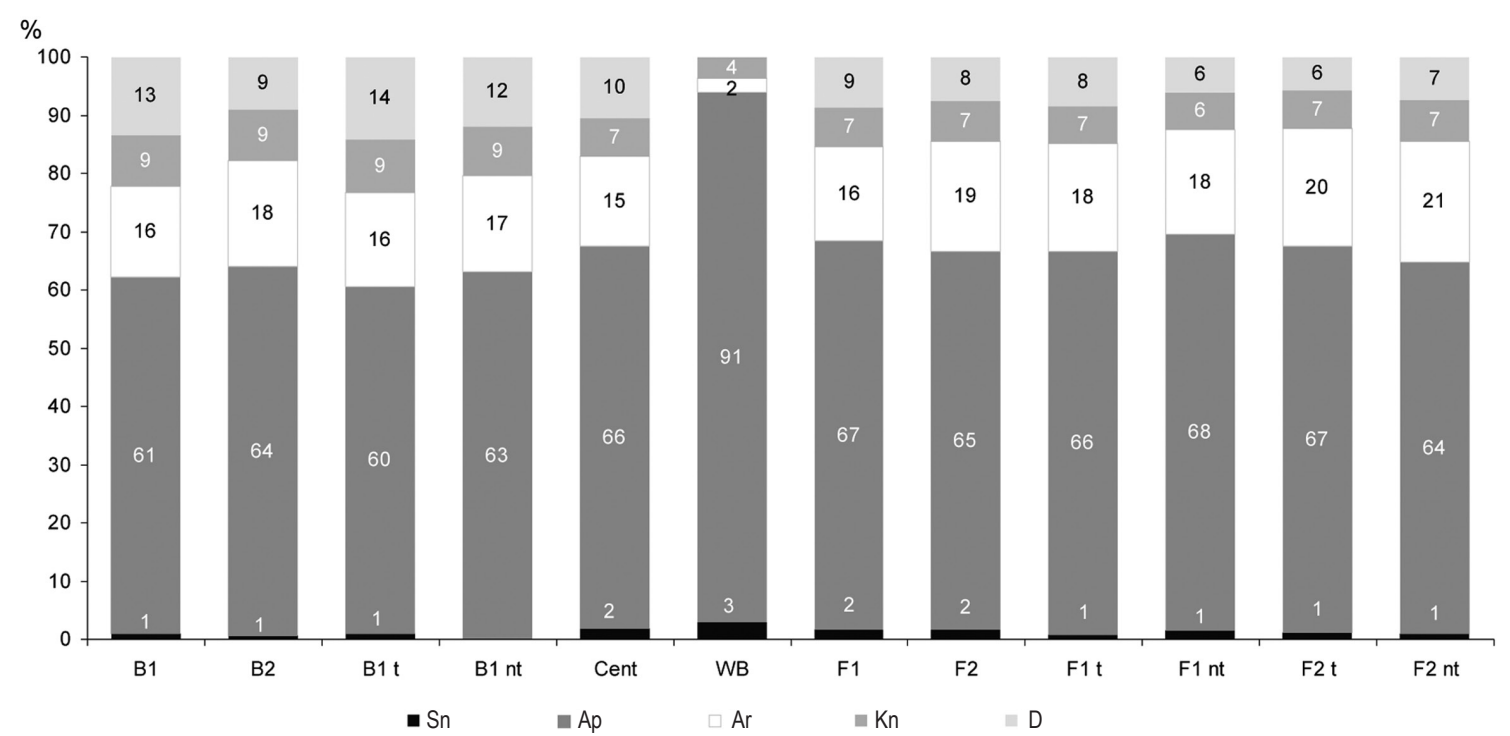

Fig. 6. Contribution of geographic-historical groups to the flora of analysed spatial complexes

Explanations: spatial complexes see Table 1, Sn - non-synanthropic spontaneophytes, Ap - apophytes, Ar - archaeophytes, Kn - kenophytes, D - diaphytes

contribution of agriophytes was rather similar except for water bodies, where 4 species of agriophytes (Acorus calamus, Aster lanceolatus, Bidens frondosa and Elodea canadensis) constituted $80 \%$ of kenophytes. The second highest percentage for this group was found in farther located arable fields in the villages with transformed structure-F2 t, and the lowest in the traditional built-up area of untransformed village B1 nt, as well as in farther located arable fields in the not transformed village F2 nt. The percent contribution of epekophytes was the highest in farther located arable fields in untransformed villages - F2 nt, and the lowest in the central green and traditional built-up area of transformed village (B1 t). In the group of diaphytes, the ephemerophytes were noted occasionally. The highest percent of ergasiophytes was recorded in the traditional built-up areas and the lowest in farther located arable fields complexes in transformed villages. The comparison of share of geographichistorical groups in transformed and not transformed settlements revealed that the differences among them were very small (Tab. 2).

Analysis of the contribution of particular geographichistorical groups in the three types of surrounding landscape (Fig. 8) revealed that spontaneophytes were

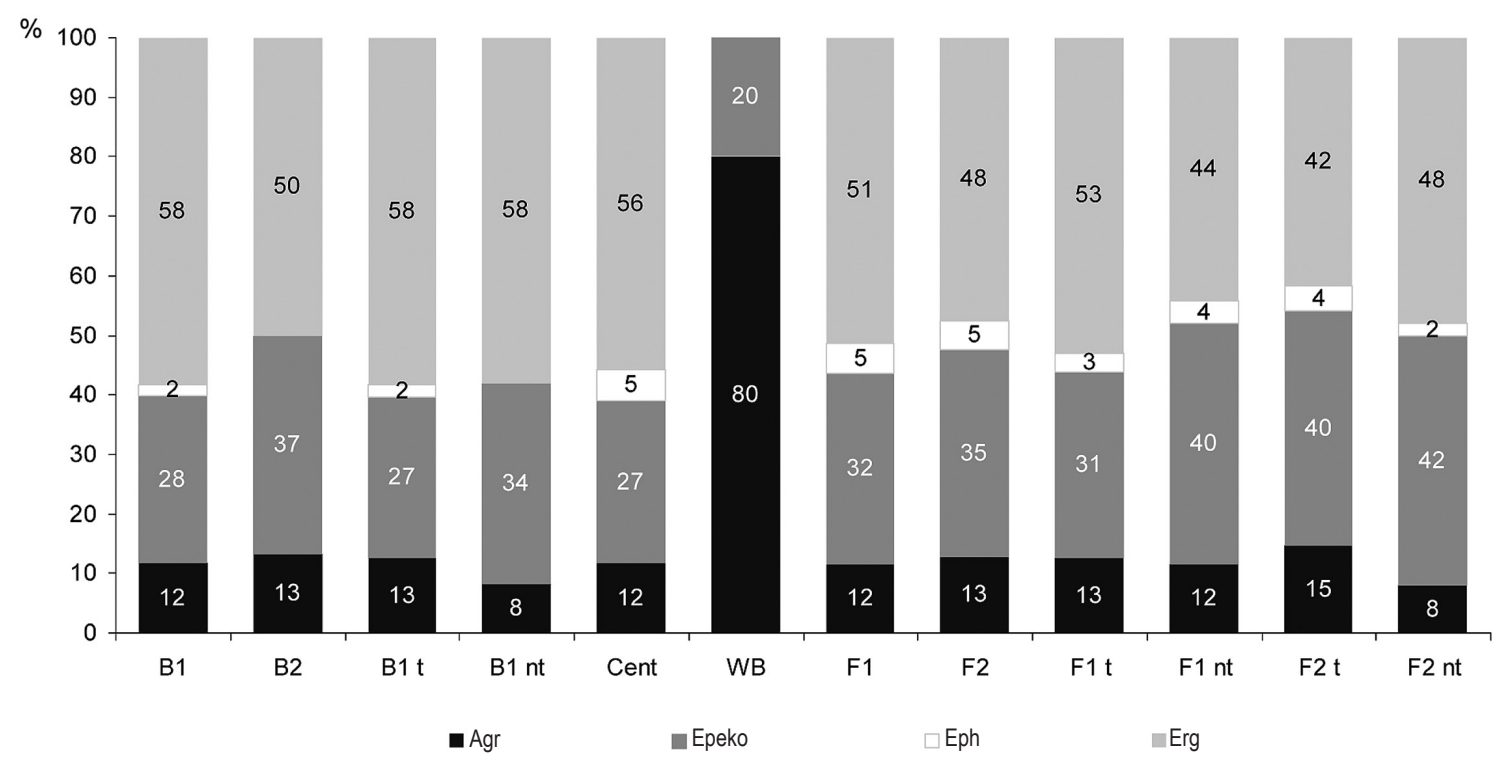

Fig. 7. Contribution of particular groups of kenophytes and diaphytes in the analysed spatial complexes

Explanations: spatial complexes see Table 1; Agr - agriophytes, Epeko - epekophytes, Eph - ephemerophytes, Erg - ergasiophytes 


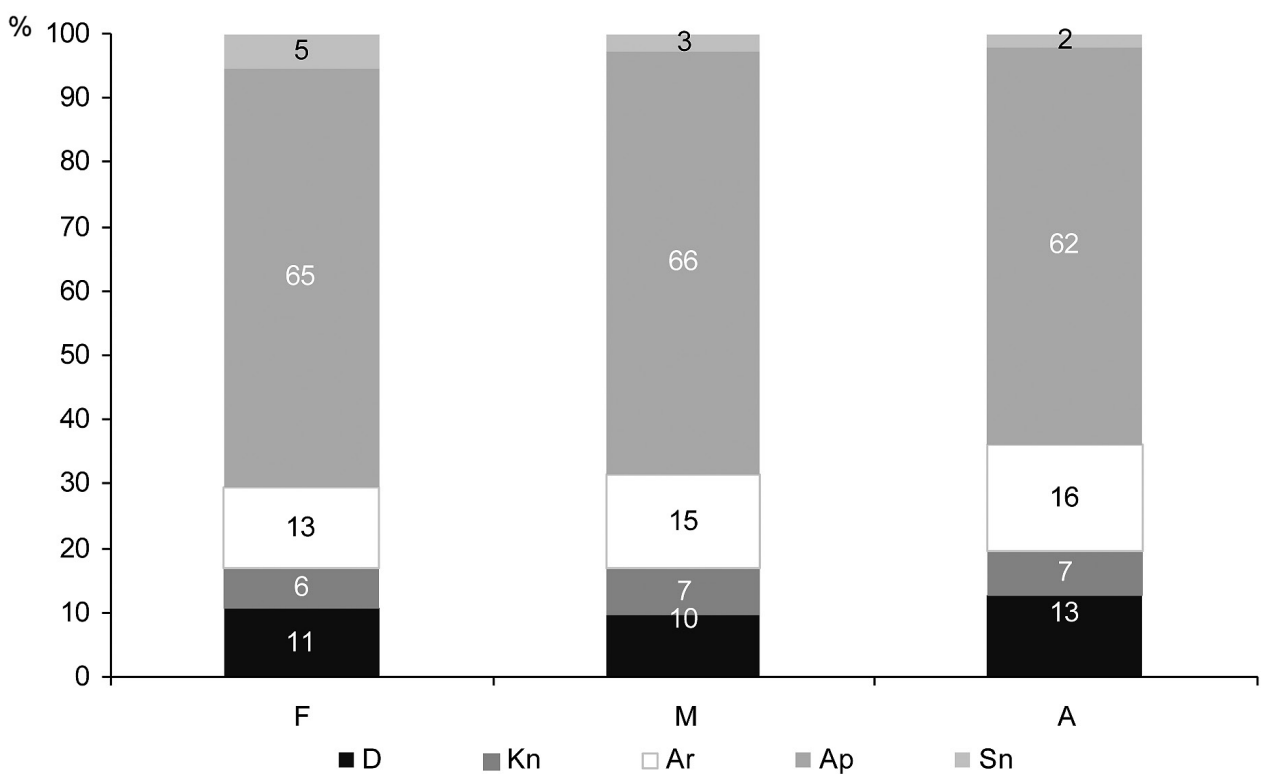

Fig. 8. Contribution of geographic-historical groups to the flora in three types of surrounding landscape

Explanations: D - diaphytes, $\mathrm{Kn}$ - kenophytes, $\mathrm{Ar}$ - archaeophytes, $\mathrm{Ap}$ - apophytes, $\mathrm{Sn}$ - non-synanthropic spontaneophytes ; F - villages located in forest type landscape, $\mathrm{M}$ - villages located in mixed landscape, $\mathrm{A}$ - villages located in arable landscape

more frequent in villages surrounded by forests, meadows and pastures (F landscape type) in comparison to the landscape A of arable fields. The percentages of apophytes in all types of landscapes were similar (on average $-64 \%$ ), but the number of this group of taxa was the highest in $\mathrm{F}$ landscape villages -439 , and the lowest in A -340 species. In case of diaphytes and kenophytes, the percentages in all groups were similar. The percent of archaeophytes recorded in the villages surrounded mostly by arable fields (A) was slightly higher $(16 \%$ versus $13 \%$ ) than that in the villages located in the $\mathrm{F}$ type landscape.

\subsection{Urbanophilic and urbanophobic species}

The contribution of urbanophilic (Fig. 9) species was low in all spatial complexes. The highest value was noted in the traditional built-up area (3\% - 9 taxa, e.g. Alcea rosea, Antirrhinum majus, Eragrostis minor and Rhus typhina). In water bodies the occurrence of species from this group was not stated. The average contribution of moderately urbanophilic species was $10 \%$, varying from $4 \%$ (i.e. 4 species on the verges of seasonally drying ponds: Arctium lappa, Artemisia vulgaris, Chelidonium majus, Lactuca serriola) to $13 \%-45$ taxa in both types of built-up areas with such commonly occurring

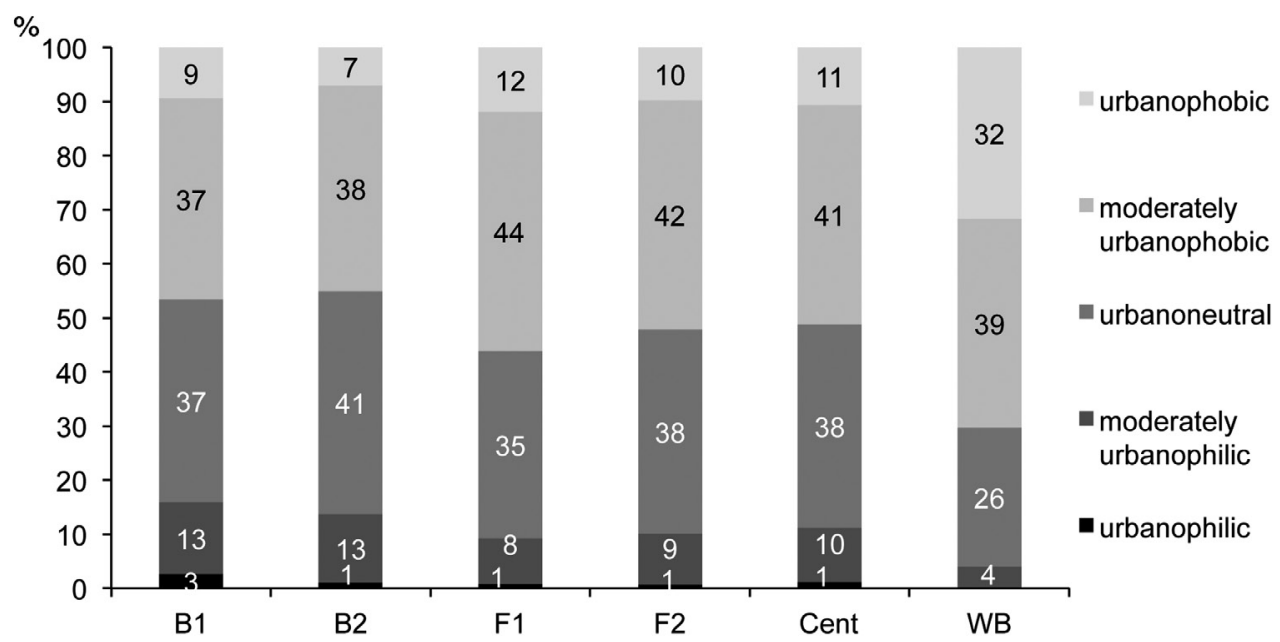

Fig. 9. Contribution of urbanophobic and urbanophilic species in the analysed spatial complexes Explanations: see Table 1 
Table 3. Indices of anthropogenic changes of flora in the studied villages

\begin{tabular}{lcc}
\hline Index name & \multicolumn{1}{c}{ Index formula } & Value \\
\hline Total synathropization & $\mathrm{WSt}=\frac{A p+A n}{S p+A n} \cdot 100 \%$ & 94.8 \\
Total apophytization & $\mathrm{WApt}=\frac{A p}{S p+A n} \cdot 100 \%$ & 72.0 \\
Spontaneophyte apophytization & $\mathrm{WAp}=\frac{A p}{S p} \cdot 100 \%$ & 92.4 \\
Total anthropophytization & $\mathrm{WAnt}=\frac{A n}{S p+A n} \cdot 100 \%$ & 31.8 \\
Total archaeophytization & $\mathrm{WArt}=\frac{A r}{S p+A n} \cdot 100 \%$ & 12.6 \\
Total kenophytization & $\mathrm{WKnt}=\frac{K n}{S p+A n} \cdot 100 \%$ & 06.6 \\
Flora modernization & $\mathrm{WM}=\frac{K n}{M} \cdot 100 \%$ & 34.5 \\
\hline
\end{tabular}

Explanations: see Material and methods

species as: Artemisia vulgaris, Ballota nigra, Chelidonium majus, Malva neglecta, and rarely occurring: Acer negundo, Lunaria annua or Oxalis corniculata. In all complexes, the urbanoneutral and moderately urbanophobic species formed together the dominant group. In almost all complexes they constitute from 75 to $80 \%$, with exception of water bodies, where their share attains only $65 \%$. The most commonly noted urbanoneutral species were: Aegopodium podagraria, Anthriscus sylvestris, Dactylis glomerata, Galium aparine, Poa annua, Poa trivialis, Sambucus nigra, Stellaria media and Urtica dioica, whereas moderately urbanophobic species included: Arrhenatherum elatius, Crataegus monogyna, Fraxinus excelsior, Quercus robur, Rosa canina, Rumex acetosa, Trifolium pratense and Viola arvensis. The highest contribution of urbanophobic species was found in water bodies (31\%), e.g.: Carex vulpina, Ceratophyllum submersum, Iris pseudacorus, Salix cinerea and Scirpus sylvaticus, and the lowest in the transformed built-up complex (7\%), e.g.: Festuca arundinacea, Helichrysum arenarium, Pimpinella nigra and Stellaria pallida.

3.5. Indices of anthropogenic changes of vascular flora

Table 3 presents values of particular indices of anthropogenic changes in the total flora of studied villages. The first three indices, i.e., total synatropization (WSt), total apophytization (WApt) and spontaneophytes apophytization (WAp), reached remarkably high values because of the high contribution of apophytes to the flora of the studied areas. The values of remaining indices were lower. The comparison of values of two indices (total anthropophytization and flora modernization) in the studied spatial complexes revealed that in the case of water bodies, the WAnt index is significantly lower, whereas WM value is much higher than in all other complexes (Table 4).

Table 4. Indices of total anthropophytization and flora modernization in different spatial complexes

\begin{tabular}{lcc}
\hline & $\begin{array}{c}\text { Total anthropophytization } \\
\text { of flora }\end{array}$ & $\begin{array}{c}\text { Flora } \\
\text { modernization }\end{array}$ \\
\hline B1 & 37.8 & 36.3 \\
B2 & 36.0 & 33.0 \\
Cent & 32.4 & 30.3 \\
WB & 06.0 & 62.5 \\
F1 & 31.6 & 29.3 \\
F2 & 33.4 & 26.5 \\
\hline
\end{tabular}

Explanations: see Table 1

\subsection{Characteristics of chosen anthropophytes in the studied villages}

Table 5 shows the representatives of relics of former cultivation according to Brandes (1996) and Celka (2011), and endangered and/or rare archeophytes. To the first group belong, e.g.: Anthriscus caucalis, Bunias orientalis, Chaerophyllum bulbosum, Malva alcea and Valerianella locusta, which occurred mainly outside the built-up complexes, and Anthriscus cerefolium, Artemisia absinthium, Chenopodium bonus-henricus, Hyoscyamus niger or Verbena officinalis, connected mostly with the built-up areas. Among rare archaeophytes, there were found 2 species with EN - endangered category of threat, 10 species with VU - vulnerable category, and 
Table 5. List of the most interesting anthropophytes in the analysed villages

\begin{tabular}{|c|c|c|c|}
\hline Species name & Frequency & Relics & Threat \\
\hline Agrostemma githago & frequent & - & VU \\
\hline Alopecurus myosuroides & very rare & - & - \\
\hline Anthemis cotula & very rare & - & - \\
\hline Anthriscus caucalis & frequent & castles & VU \\
\hline Anthriscus cerefolium & extremely rare & castles & - \\
\hline Aphanes inexspectata & extremely rare & - & DD \\
\hline Artemisia absinthium & very frequent & medieval or modern & - \\
\hline Avena fatua & frequent & - & DD \\
\hline Bromus secalinus & rare & - & VU \\
\hline Bunias orientalis & extremely rare & medieval & - \\
\hline Camelina sativa & extremely rare & medieval & VU \\
\hline Carduus nutans & extremely rare & - & - \\
\hline Chaerophyllum bulbosum & common & medieval & - \\
\hline Chamomilla recutita & very frequent & - & VU \\
\hline Chenopodium bonus-henricus & rare & castles & - \\
\hline Conium maculatum & very rare & castles & - \\
\hline Coronopus squamatus & extremely rare & - & $\mathrm{EN}$ \\
\hline Gagea arvensis & very rare & - & EN \\
\hline Galium spurium & very rare & - & - \\
\hline Geranium dissectum & very rare & - & - \\
\hline Hyoscyamus niger & extremely rare & castles & - \\
\hline Isatis tinctoria & extremely rare & castles & - \\
\hline Lathyrus tuberosus & rare & - & VU \\
\hline Leonurus cardiaca & very frequent & medieval castles & - \\
\hline Lycium barbarum & frequent & modern & - \\
\hline Malva alcea & rare & medieval & - \\
\hline Portulaca oleracea & very rare & - & VU \\
\hline Valerianella locusta & frequent & medieval & - \\
\hline Verbena officinalis & frequent & castles & - \\
\hline Veronica agrestis & rare & - & VU \\
\hline Veronica polita & rare & - & VU \\
\hline Vinca minor & very frequent & medieval or modern & - \\
\hline Viola odorata & common & medieval or modern & - \\
\hline
\end{tabular}

Explanations: relics acc. to Brandes (1996) and Celka (2011), category of threat acc. to Zając et al. (2009)

2 species with category DD - data deficient. Additionally, some archaeophytes rare in the region were listed: Alopecurus myosuroides, Anthemis cotula, Carduus nutans, Galium spurium and Geranium dissectum.

\section{Discussion}

The diversity of flora in the analysed villages, expressed as species richness, is rather high. It is comparable or even higher than that stated in other Central European villages (123 to 346, mean 226 - Pyšek 1998a; Ahrns 2009), or in 59 German villages (79 to 191, mean 137 and total 509 - Knapp \& Wittig 2012).

The pattern of contribution to frequency classes is bimodal - most numerous are extremely rare and common species. The percentage of common species noted in $15-30$ villages exceeded 30\%. Extremely rare species, i.e., recorded in only $1-2$ villages, amounted to $27 \%$. Very rare and rare species jointly amounted to $29 \%$, while frequent species accounted for $12 \%$. Similar distribution of frequency classes obtained Wołkowycki (2000a) in the eastern Poland, where the group of common species (which occurred in $60-100 \%$ of settlements) was also numerous $-26 \%$, while the group of rare species (which occurred in less than $20 \%$ of settlements) amounted to 49\%. Opposite results obtained Wittig \& Rückert (1985) as an effect of the analysis of flora of 200 villages, where the most numerous frequency classes were those of rare and extremely rare species (in less than $10 \%$ of villages). Even more extreme distribution of frequency classes got Celka (2011) from early medieval and medieval archaeological sites. The common species (which occurred in $55-100 \%$ of those sites) amounted only to $1,6 \%$, whereas rare and extremely rare (in less than $6 \%$ of sites) to $54 \%$. 
The high share of common species in the analysed villages of Lubuskie Lakeland might result from their spatial similarity. They represent only one type of village structure - that with oval shape. Another reason may be the number of villages (30), the relatively small area of studies $\left(5,000 \mathrm{~km}^{2}\right)$ and the homogeneity of landscape - settlements were located only in one macroregion (Kondracki 1998) as compared to that of Wittig \& Rückert (1985 - 200 villages in $34,000 \mathrm{~km}^{2}$ ) and Celka (2011 - 100 sites in the total area of Poland, 4 in NE Germany, 5 in Czech Republic in very different landscapes). Knapp \& Wittig (2012) have shown that total flora of 59 villages was richer and significantly more similar among villages in the period 2004-2005 as compared to 1980-1984. That fact may indicate the process of homogenization of settlement flora. Wołkowycki (2000a, 2000b) states that the number of analysed villages may influence the contribution of common species. Following this explanation, similar contribution of frequency classes with high proportion of both common and rare species obtained Wittig \& Alberternst (2005) as result of analysis of only 14 villages in Germany. Other interesting results obtained Huwer \& Wittig (2013). These authors observed that in the period of 21 years since the first investigation, the percentage of most frequent species doubled. Similarly like in this study, in the group of common species prevailed ubiquitous plants, which were spread in many towns, cities, along roads and margins of fields and meadows. Similar possible explanations for this pattern gave Kühn \& Klotz (2006), who interpreted the increase in the share of common native plant species as a result of decline of different rare species as a consequence of urbanization.

In the studied area, the flora of settlements was dominated by native plants $(67 \%)$. In the group of alien species the contribution of archaeophytes was the same as of diaphytes (13\% each), while the contribution of newly introduced species - kenophytes was the lowest $(7 \%)$. Similar results were noted in other studies in Central-European villages. Ahrns (2009) in the analysis of 56 villages in Germany and Czech Republic noted $64 \%$ of native species, $17 \%$ archaeophytes, $17 \%$ agriophytes and $2 \%$ of species were not assignable. In the settlements of central Pomerania the contributions of geographic-historical groups were also similar (Kalwasińska-Brojek \& Markowski 2005). The share of apophytes amounted there to $67 \%$ and anthropohytes to $33 \%$ (among them: archaeophytes $-18 \%$, kenophytes $-6 \%$ and ergasiophytes $-9 \%$ ). In the ruderal flora of the eastern Poland, a relatively high contribution of ergasiophytes was noted $-21 \%$ (Wołkowycki 2000a). The low share of this group in other studies can be explained by the different attitude towards recording the species that escaped from cultivation. The higher number of apophytes and archaeophytes and the lower number of kenophytes or ergasiophytes might be explained by the degree of human disturbance expressed by settlement size (Wołkowycki 2000a, 2000b). Other factors affecting the contribution of particular groups of species are: the surrounding landscape, the number of inhabitants and transformation of the village (Kornaś 1977). For example, in the abandoned villages, surrounded mostly by meadows and forests, the share of archaeophytes was low - 13\% (Kirpluk 2011), whereas in the villages surrounded by arable fields, they constituted more than $20 \%$ (Wołkowycki 2000a). Generally, the floras of archaeophytes in a given region, e.g, in the Kampinos Forest or in Podlasie, are highly homogenous, which may result from long time of their spread, the species biology and in the case of Podlasie of still existing resources (Wołkowycki 2000a; Kirpluk 2011).

Kalwasińska-Brojek \& Markowski (2005) analysed the influence of surrounding landscape on the village flora. Authors indicated that in the villages surrounded mostly by forests and meadows, contrary to villages surrounded by arable fields, the contributions of apophytes were higher, while kenophytes and ergasiophytes lower. Another factor which influenced the contribution of particular geographic-historical groups might be the time. The analyses of Pyšek \& Mandák (1997), Brunzel et. al. (2009) and Knapp \& Wittig (2012) revealed increase in, i.a., agriophytes in time. The diversity of geographic-historical groups may also be influenced by urbanization (Kühn \& Klotz 2006). Native and archaeophytes were more homogenous, while kenophytes more heterogeneous within urbanized areas in comparison to rural areas.

The affinity toward urban areas expressed by categories of urbanity may be used to evaluate process of de-ruralisation (Huwer \& Wittig 2013). In our study, the contribution of urbanophilic species was the lowest compared to other groups. The most numerous were urbanoneutral and moderately urbanophobic species. The differences in particular spatial complexes were observed. For example, the highest contribution of urbanophilic species was noted in the built-up area, whereas in water bodies - of urbanophobic species. The contribution of moderately urbanophilic, urbanoneutral and urbanophobic species is similar within built-up areas and in central green, whereas field complexes, both adjoining the village as well as located outside of the road, showed a high degree of reciprocal similarity, but were different from previously mentioned complexes.

It is interesting to compare the different types of settlements in respect to the indices of flora anthropophytization. The degree of transformation of analysed villages expressed by indices of total anthropophytization and spontaneophyte apophytization 
is higher in comparison to a city (Jackowiak 1990) or archaeological sites (Celka 2011). This result can be explained by a smaller number of habitats in the studied villages, where non-synanthropic spontaneophytes might have occurred, such as: natural forest, meadows, grasslands or lakes, and, on the other hand, a high proportion of anthropogenic habitats where apophytes occurred. The index of total archaeophytization was higher in the analysed villages than in a city as compared to the data of Jackowiak (1990) or in archaeological sites (Celka 2011). The indices of total kenophytization and flora modernization were smaller than in a city (Jackowiak 1990) and similar to those of archaeological sites (Celka 2011).

In the analysed villages, 17 relics of former cultivation, as well as 18 rare archaeophytes were found. Among them, 14 species were threatened according to the list of Zając et al. (2009). In 15 abandoned villages in the Kampinos Forest (Kirpluk 2011) 7 threatened species of archeophytes were found.

\section{Conclusions}

- In the flora of rural areas, native species distinctly prevailed over alien in all types of spatial complexes, albeit the majority of them occurred in habitats transformed by man.

- The differences in the floristic composition of transformed and non-transformed villages were not significant at the level of whole village.

- The index of anthropophytization of flora calculated for different types of complexes had shown that both types of built-up areas showed the highest values, slightly higher than fields and central green. Index of flora modernization showed the same pattern. Only water bodies were strikingly different from other complexes in respect to both indices ( $\mathrm{WAn}_{\mathrm{t}}-$ significantly lower values and $\mathrm{WM}$ - much higher).

- The villages were still harbouring rare species from the group of relics of former cultivation and of archaeophytes but their number was decreasing as it has been confirmed by observations conducted since the year 2007.

- The comparisons with German villages have shown that the flora of villages in the Lubuskie Lakeland was much richer in species than that of NordrheinWestfalen. The scope and possible explanations of this phenomenon will be discussed in another publication.

- The process of urbanization of villages (including the decreasing number of people living from farming), connected with their depopulation, will in future contribute to the change of category of urbanity of the flora. These studies gave basic information gathered in the mid of this process.

- The percentages of groups of species with different affinity toward urban areas have shown that in the studied rural areas, the share of urbanophilic species was still very low as compared to the dominant group of urbanoneutral and moderately urbanophobic species.

Acknowledgements. Authors thank prof. dr hab. Karol Latowski for identification or verification of some herbarium specimens. Financial support came from the National Science Center Grant NN 305062440.

\section{References}

Ahrns C. 2009. The ecological indication content of Central European village floras. Ecol Indicators 9: 605-620.

Balcerkiewicz S. \& Pawlak G. 2010. Spontaneofity w zbiorowiskach segetalnych Polski. Fragm. Agron. 27(3): 7-19.

Borysiak J., Kasprowicz M. \& PaWlak G. 2000. Roślinność rzeczywista miasta Pniewy na Pojezierzu Poznańskim w ujęciu kartograficznym i fitosocjologicznym. Bad. Fizjogr. Pol. Zach. seria B - Botanika 49: 173-184.

BRANDES D. 1996. Naturschutzaspekte bei der Denkmalpflege unter besonderer Berücksichtigung der Mauervegetation. Berichte der ANL 20: 145-149.

Brandes S. \& Brandes D. 1996. Flora und Vegetation von Dörfern im westlichen Sachsen-Anhalt. Braunsch. Naturkdl. Schr. 5(1): 165-192.

Brunzel S., Fischer S. F., Schneider J., Jetzkowitz J. \& BRANDL R. 2009. Neo- and archaeophytes respond more strongly than natives to socio-economic mobility and disturbance patterns along an urban-rural gradient. J. Biogeogr. 36: 835-844.
Brzeg A., Szrama K. \& Wojterska M. 2013. Rzadsze gatunki flory naczyniowej terenów wiejskich Pojezierza Lubuskiego. Bad. Fizjogr. RII, seria B (B62): 145-159.

Brzeg A., Szrama K. \& Wojterska M. 2014. Rzadsze gatunki flory naczyniowej terenów wiejskich Pojezierza Lubuskiego. Cz. II. Bad. Fizjogr. RV, seria B (B63): 117-130.

BurszTA J. 1958. Od osady słowiańskiej do wsi współczesnej. O tworzeniu się krajobrazu osadniczego ziem polskich i rozplanowań wsi. 176 pp. Wyd. Zakład Narodowy im. Ossolińskich, Wrocław.

CELKa Z. 2011. Relics of cultivation in the vascular flora of medieval West Slavic settlements and castles. Biodiv. Res. Conserv. 22: 1-110.

Drake J. A., Mooney H. A., di Castri F., Groves R. H., Kruger F. J., Rejmánek M. \& Williamson M. (eds.). 1989. Biological Invasions: a Global Perspective. 550 pp. John Wiley and Sons, Chichester.

FALIŃSKI J. B. 1969. Zbiorowiska autogeniczne i antropogeniczne. Próba określenia i klasyfikacji. Ekol. Pol., B, 15(2): 173-182. 
FALIŃSKI J. B. 1971. Flora i roślinność synantropijna miast i wsi - próba analizy porównawczej. Mater. Zakł. Fitosoc. Stos. UW 27: 15-37.

Gunton R. M., Petit S. \& Gaba S. 2011. Functional traits relating arable weed communities to crop characteristics. Journal of Vegetation Science 22: 541-550.

HANSKI I. 1982. Distributional ecology of anthropochorous plants in villages surrounded by forest. Ann. Bot. Fennici 19: 1-15.

Huwer A. \& Wittig R. 2013. Evidence for increasing homogenization and de-ruralization of the Central European village flora. Tuexenia 33: 213-231.

JACKOWIAK B. 1990. Antropogeniczne przemiany flory roślin naczyniowych Poznania. Wyd. Nauk. UAM, seria Biologia, 42, 232 pp. Poznań.

JACKOWIAK B. 1998. Struktura przestrzenna flory dużego miasta. Studium metodyczno-problemowe. Prace Zakładu Taksonomii Roślin UAM w Poznaniu 8: 1-228. Bogucki Wyd. Nauk., Poznań.

Kalwasińska-Brojek G. \& Markowski R. 2005. Zróżnicowanie flor synantropijnych wybranych osiedli wiejskich Borów Tucholskich i Pojezierza Starogardzkiego (północna Polska). Acta Bot. Cassub. 5: 57-69.

Kim Y.-M., Zerbe S. \& Kowarik I. 2002. Human impact on flora and habitats in Korean rural settlements. Preslia 74: 409-419.

KIRPLUK I. 2011. Najstarsi przybysze we florze ruderalnej opuszczonych wsi Kampinoskiego Parku Narodowego. Acta Botanica Silesiaca 7: 97-112.

KIRPLUK I. 2012. The most recent alien species of the ruderal flora in the abandoned villages of the Kampinos National Park (Central Poland). Thaiszia J. Bot. 22(2): 143-153.

KnApp S. \& Wittig R. 2012. An analysis of temporal homogenisation and differentiation in Central European village floras. Basic and Applied Ecology 13: 319-327.

Kondracki J. 1998. Geografia regionalna Polski. 441 pp. Wyd. Nauk. PWN, Warszawa.

KornAś J. 1968. Geograficzno-historyczna klasyfikacja roślin synantropijnych. Mater. Zakł. Fitosoc. Stos. U.W. 25: 33-41.

Kornaś J. 1977. Analiza flor synantropijnych. Wiad. Bot. 21(2): 85-91.

Kornaś J. \& Medwecka-Kornaś A. 2002. Geografia roślin. 634 pp. Wyd. Nauk., PWN Warszawa.

KowARIK I. 1990: Some responses of flora and vegetation to urbanization in Central Europe. In: H. SuKopp; S. HeJnY \& I. KowARIK (eds.). Urban ecology, pp. 45-74. The Hague.

KÜHn I., BRAnDL R. \& Klotz S. 2004a. The flora of German cities is naturally species rich. Evol. Ecol. Res. 6: 749-764.

Kühn I., Durka W. \& Klotz S. 2004b. BiolFlor - a new plant-trait database as a tool for plant invasion ecology. Diversity Distrib. 10: 363-365.

KüHN I. \& KLOtz S. 2006. Urbanization and homogenization. Comparing the floras of urban and rural areas in Germany. Biological Conservation 127: 292-300.

Lososová Z., Chytrý M., Cimalová Š ., Kropáč Z., OtÝPKovÁ Z., Pyšek P. \& TichÝ L. 2004. Weed vegetation of arable land in Central Europe: Gradients of diversity and species composition. Journal of Vegetation Science 15: 415-422.

LososovÁ Z. \& Cimalová Š. 2009. Effects of different cultivation types on native and alien weed species richness and diversity in Moravia (Czech Republic). Basic and Applied Ecology 10: 456-465.

Matuszkiewicz J. M. 1993. Krajobrazy roślinne i regiony geobotaniczne Polski. Prace Geogr. 158, pp. 107. Wrocław, Warszawa, Kraków.

McGarigal K., Cushman S.A. \& Ene E. 2012. FRAGSTATS v4: Spatial Pattern Analysis Program for Categorical and Continuous Maps. Computer software program produced by the authors at the University of Massachusetts, Amherst. http://www.umass.edu/landeco/ research/fragstats/fragstats.html

MireK Z. 1981. Problemy klasyfikacji roślin synatropijych. Wiad. Bot. 25(1): 45-54.

Mirek Z., Piękoś-Mirkowa H., Zając A. \& Zając M. 2002. Flowering plants and pteridophytes of Poland. A checklist. In: Z. MireK (ed.). Biodiversity of Poland, 1, 442 pp. W. Szafer Institute of Botany, Polish Academy of Sciences, Kraków.

Nitz H. J. 1998. The slavic hamlet round a cult green as the precursor of the regular rundling of the medieval Frankish-German Colonisation. Erdkunde 52: 144-162.

Pal W. R., Csete S., Botta-Dukát Z. \& Pinke G. 2013. Composition and diversity of lawn flora in differently managed village yards - a case study from southwestern Hungary. Folia Geobot. 48: 209-227.

PYŠEK P. 1998a. Alien plants in Czech village flora. Feddes Repert. 109: 139-146.

PYŠEK P. 1998b. Alien and native species in Central European urban floras: a quantitative comparison. J. Biogeogr. 25: 155-163.

Pyšek P., Jarošík V., ChytrÝ M., KropÁč Z., TichÝ L. \& Wild J. 2005a. Alien plants in temperate weed communities: prehistoric and recent invaders differ in habitat affinities. Ecology 86: 772-785.

PyŠEK P., JARošík V., KROPÁČ Z., ChYTRÝ M., Wild J., \& TichÝ L. 2005b. Effects of abiotic factors on species richness and cover in Central European weed communities. Agriculture Ecosystem \& Environment 109: 1-8.

PYŠEK P. \& MANDÁK B. 1997: Fifteen years of changes in the representation of alien species in Czech village flora. In: J. H. Brock, M. WAdE, P. PyŠEK \& D. GReEN (eds.). Plant invasions. Studies from North America and Europe, pp. 183-190. Backhuys Publishers, Leiden.

Pyšek P., Prach K., Rejmánek M. \& Wade M. (eds.). 1995. Plant invasions - General aspects and special problems. 263 pp. SPB Academic Publ., Amsterdam.

Pyšex P., SÁdlo J. \& MAndÁK B. 2003. Alien flora of the Czech Republic, its composition, structure and history. In: L. E. Child, J. H. Brock, G. Brundu, K. Prach, P. PYŠEK, P. M. WAdE \& M. Williamson (eds.). Plant invasions: Ecological threats and management solutions, pp. 113-130. Backhuys Publishers, Leiden.

RaAbe U. \& Brandes D. 1988. Flora und Vegetation der Dörfer im nordöstlichen Burgenland. Phytocoenologia 16(2): 225-258. 
RatyŃSKa H., Wojterska M., Brzeg A. \& KoŁacz M. 2010. Multimedialna encyklopedia zbiorowisk roślinnych Polski Ver. 1.1. NFOSiGW, UKW, IETI, Bydgoszcz.

Sudnik-Wójcikowska B. 1998. Czasowe i przestrzenne aspekty procesu synatropizacji flory na przykładach wybranych miast Europy Środkowej. 167 pp. Wyd. Uniw. Warszawskiego, Warszawa.

Sukopp H. (ed.). 1990. Stadtökologie. Das Beispiel Berlin. 455 pp. Reimer, Berlin.

Thellung A. 1915. Pflanzenwanderungen unter dem Einfluss des Menschen. Englers Bot. Jahr. 53, Beibl. 116(3-5): 37-68.

TokARSKA-GuZIK B. 2005. The Establishment and Spread of Alien Plant Species (Kenophytes) in the Flora of Poland. Prace naukowe Uniw. Śląskiego w Katowicach 2372: 1-192.

TOKARsKa-GuZIK B., DAJdok Z., ZajĄC M., ZAJĄC A., UrbisZ A., Danielewicz W. \& HoŁdyński C. 2012. Rośliny obcego pochodzenia w Polsce ze szczególnym uwzględnieniem gatunków inwazyjnych. 197 pp. Generalna Dyrekcja Ochrony Środowiska, Warszawa.

Weibull A.-Ch. \& Östman Ö. 2003. Species composition in agroecosystems: The effect of landscape, habitat, and farm management. Basic and Applied Ecology 4: 349-361.

Wittig R. 1984. Sterben die Dorfpflanzen aus? Ergebnisse einer umfassenden Untersuchung der Dorfflora in 180 Dörfen Nordrhein-Westfalens. Der Gemeinderat 27: 36-37.

Wittig R. 2008. Gartenflüchtlinge als neue Mitglieder der Dorfflora in Nordrhein-Westfalen. Braunschweiger Geobotanische Arbeiten 9: 481-490.

Wittig R. \& Alberternst B. 2005. Flora der Dörfer des Hochtaunus. Geobot. Kollog. 18: 35-50.

Wittig R., Diesing D. \& Gödde M. 1985. Urbanophob, urbanoneutral, urbanophil. Das Verhalten der Arten gegenüber dem Lebensraum Stadt. Flora 177: 265-282.

Wittig R. \& Rückert E. 1985. Die spontane Flora im Ortsbild nordrhein-westfälischer Dörfer. Siedlung und Landschaft in Westfalen 17: 107-154.

Wojterska M., RATYŃSKA H. \& RĄCZKOWSKI W. 2007a. Vegetation of rural settlements in Western Poland versus their spatial structure and history. In: Cultural Landscapes Changing Landscapes. The International Association for Vegetation Science: 50th Annual Symposium University of Swansea, 23-27.07.2007, pp. 46-47.
Wojterska M., RatyŃSKa H. \& RĄCZKowsKi W. $2007 \mathrm{~b}$. Współczesna struktura krajobrazu roślinnego średniowiecznych założeń osadniczych w zachodniej Polsce. In: W. Dreszer (ed.). Sztuka projektowania krajobrazu. Materiały z międzyuczelnianej konferencji „Architektura krajobrazu kulturowego”, ASP, Poznań, pp. 74-79.

Wojterski T., Leszczyńska M. \& Piaszyk M. 1973. Potencjalna roślinność naturalna Pojezierza Lubuskiego. Bad. Fizjogr. Pol. Zach. seria B-Botanika 26: 107-142.

WoŁkowycki D. 1997. Flory ruderalne w krajobrazie wiejskim Niziny Północno-Podlaskiej - wstęp do analizy porównawczej. Fragm. Flor. Geobot. Polonica 4: 39-74.

WoŁkowycki D. 2000a. Różnicowanie i ujednolicanie się flor ruderalnych w warunkach izolacji środowiskowej. Monogr. Bot. 87: 1-164.

WoŁKowycKi D. 2000b. Differentiation of ruderal floras in environmental isolation conditions. In: B. JACKOWIAK \& W. Żukowski (eds.). Mechanisms of Anthropogenic Changes of the Plant Cover. Publications of the Department of Plant Taxonomy of the A. Mickiewicz University in Poznań 10: 111-124. Bogucki Wyd. Nauk., Poznań.

ZaJĄC A. 1979. Pochodzenie archeofitów występujących w Polsce. Rozpr. habil. Uniw. Jagiell, 29: 1-213. Druk UJ w Krakowie.

ZAJĄC A. \& ZAJĄC M. 2011. Methodical problems in distinguishing the group of archaeophytes. In: Z. KAcCKI \& E. STEFAŃSKA-KRZACZEK (eds.). Synantropizacja w dobie zmian różnorodności biologicznej. Acta Botanica Silesiaca 6: 55-62.

ZAJĄC M. ZAJĄC A. \& ToKARSKA-GuZIK B. 1998. Kenophytes in the flora of Poland: list, status and origin. In: J. B. FALIŃSKi, W. AdAMOWSKi \& B. JACKOWIAK (eds.). Synanthropization of plant cover in new Polish research. Phytocoenosis 10 (N.S.) Suppl. Cartogr. Geobot. 9: 107-116.

ZAJĄC M., ZAJĄC A. \& TOKARSKA-GuZIK B. 2009. Extinct and endangered archaeophytes and the dynamics of their diversity in Poland. Biodiv. Res. Conserv. 13: 17-24.

Żukowski W., Latowski K., Jackowiak B., Chmiel J. 1995. Rośliny naczyniowe Wielkopolskiego Parku Narodowego. Prace Zakładu Taksonomii Roślin UAM w Poznaniu 4: 1-229. Bogucki Wyd. Nauk., Poznań. 